\title{
LENGTH-WEIGHT RELATIONSHIP AND GROWTH PATTERN INFERENCE OF A SMALL INDIGENOUS FRESHWATER PRAWN, Macrobrachium lamarrei (H. Milne-Edwards, 1837) IN BANGLADESH
}

\author{
Motia Gulshan Ara, Md. Noor Nabi, Zoarder Faruque Ahmed and \\ Mst. Kaniz Fatema*
}

Department of Fisheries Management, Faculty of Fisheries, Bangladesh Agricultural University, Mymensingh-2202, Bangladesh

*Corresponding author: Mst. Kaniz Fatema, E-mail: kanizhossain@gmail.com

\section{ARTICLE INFO ABSTRACT}

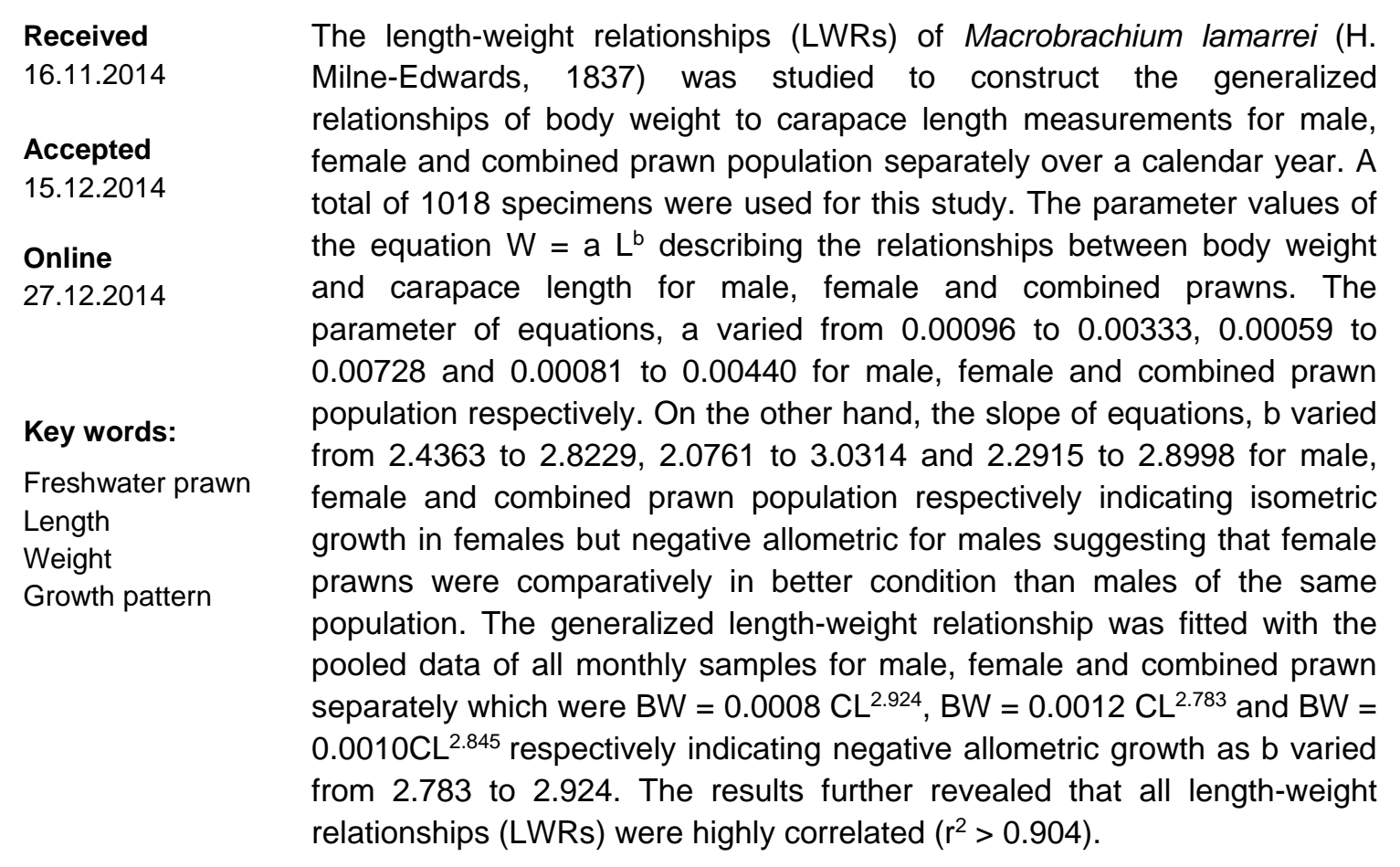

To cite this article: MG Ara, MN Nobi, ZF Ahmed and MK Fatema, 2014. Length-weight relationship and growth pattern inference of a small indigenous freshwater prawn, Macrobrachium lamarrei $(\mathrm{H}$. MilneEdwards, 1837) in Bangladesh. Res. Agric., Livest. Fish. 1(1): 137-145.

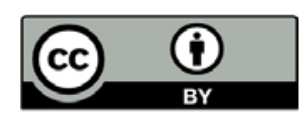

This article is an open access article licensed under the terms of the Creative Commons Attribution License.

www.agroaid-bd.org/ralf, e-mail: editor.ralf@gmail.com 


\section{INTRODUCTION}

The prawns of Palaemonidae family are very important economic resources in the world's crustacean fishery (Mantelatto and Barbosa, 2005; Hossain et al., 2012). Palaemonid prawn has also immense importance in Bangladesh as it considered one of the most important sectors of the national economy. Among different prawn species available in Bangladesh, M. lamarrei is notable one, commonly known as "kuncho river prawn" that is a small indigenous freshwater prawn belonging to the family Palaemonidae. This kuncho river prawn has found in ponds and rivers in Bangladesh, India and some other countries (Holthius, 1980). Previously, a few studies were conducted on $M$. lamarrei based on their general biology. However, in Bangladesh there is hardly any work that has been conducted on the growth and length-weight relationships (LWR) in this very valuable Palaemonid prawn species.

Length-weight relationship is very important for establishing production and biomass estimation of a species. (Anderson and Gutreuter, 1983). Sarkar et al. (2008) and Mir et al. (2012) reported that the estimation of the average weight of the fish of a given length group by establishing a mathematical relation between length-weight. The relationships between length and weight are important in fisheries management for comparative growth studies (Hossain et al., 2006). Besides this in setting yield equations for comparing the population in space and time and estimating the number of fish landed, length-weight relationship can also be used (Singh et al., 2011). Length and weight data are a useful tool for standard result of fish sampling programs. Length- weight relationships are useful for estimating standing crop biomass and seasonal variations in fish growth can also be tracked by L-W relationship (Martin-Smith, 1996). Therefore, for assessing fish stock, length- weight relationship of fish species is important and for length-weight conversion, the parameters 'a' and ' $b$ ' can be used (Pauly and Gayanilo, 1996). Furthermore, the empirical relationship between the length and weight of the fish enhances the knowledge of natural history of commercially important fish species, thus making the conservation possible.

Subsequently, the aims of the present paper is to determine the length-weight relationships of monthly samples, to construct a generalized length-weight relationship of $M$. lamarrei for male, female and combined prawn separately over a calendar year and to evaluate the growth pattern of male, female and combined populations from $L$ shaped pond at Bangladesh Agricultural University campus, Mymensingh, Bangladesh. Therefore, the present study provides baseline information for the growth of this species. The data and information will go a long way in supporting the management initiatives for the sustainability of this freshwater prawn as well as other species.

\section{MATERIALS AND METHODS}

\section{Sample collection}

M. lamarrei prawn species was collected randomly using a fine-meshed push net from the Lshaped pond situated in Bangladesh Agricultural University campus, Mymensingh, Bangladesh once in a month over a calendar year. All specimens were preserved in $10 \%$ buffered formalin soon after collection.

\section{Sex determination}

Male was identified observing second chelate legs which were extraordinary large, spiny and strong with naked eyes. Individuals confirmed as female with the presence of one pair of genital pore in the coax of third pairs of walking legs under a stereo microscope (Figure 1 and 2). 


\section{Recording of carapace length and body weight}

Carapace length $(\mathrm{CL})$ was measured from the tip of the rostrum to the posterior edge of the carapace with a slide calipers to the nearest $0.01 \mathrm{~mm}$, whilst body weight (BW) was taken with a digital balance to the nearest $0.01 \mathrm{~g}$. Detailed description of prawn sampling is given in Table 1.

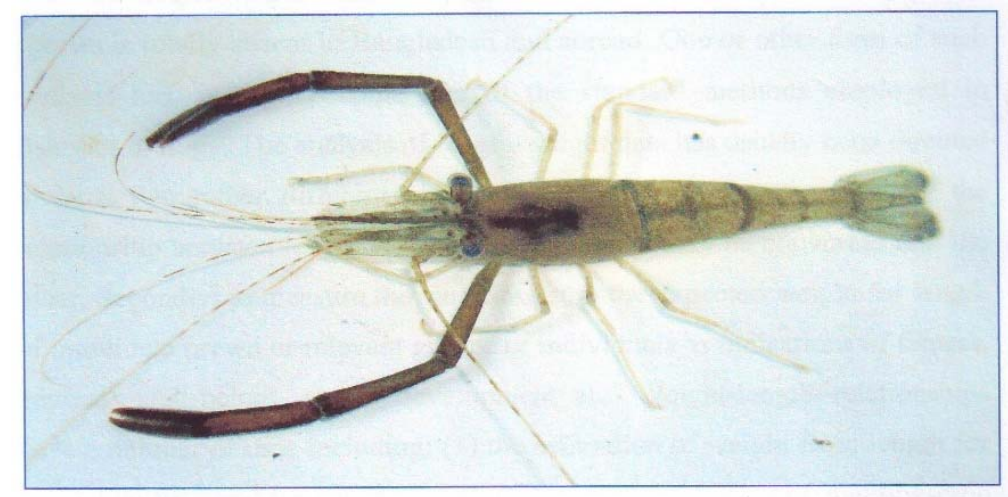

Figure 1. An image of a male freshwater prawn M. lamarrei (H. Milne-Edwards, 1837)

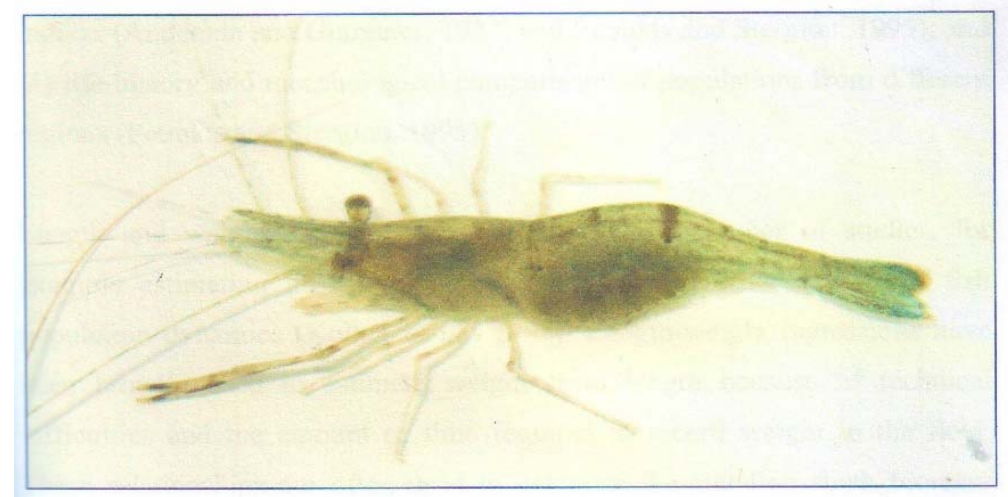

Figure 2. An image of a female freshwater prawn M. lamarrei (H. Milne-Edwards, 1837)

\section{Length - weight relationship (LWR)}

The relationship between carapace length and weight was calculated using the equation, $\mathrm{W}=\mathrm{a}$ $C L^{b}$ where coefficient ' $a$ ' is the intercept in the $y$-axis, and the regression coefficient ' $b$ ' is an exponent indicating isometric growth when equal to 3 . This equation was converted into its logarithmic expression: In $\mathrm{W}=$ In $\mathrm{a}+\mathrm{b}$ In $\mathrm{CL}$ where the parameters ' $\mathrm{a}$ ' and ' $\mathrm{b}$ ' were calculated by linear regression, as was the coefficient of determination $\left(r^{2}\right)$. To test for possible significant differences in both slope and intercept, we followed the analysis of covariance (ANCOVA). All statistical analyses were considered significant at $\mathrm{P}<0.05$.

\section{Growth pattern inference}

Growth pattern of individuals in monthly sample were determined on the basis of $b$ value in the equation $B W=a C L^{b}$. When ' $b$ ' is equal to 3 , the growth was isometric resulting an ideal shape of prawn; when the value of $b$ was less than 3.0, the growth was negative allometric and when the value of $b$ was more than 3.0, the growth was positive allometric pattern. The growth pattern of the individuals in the population was evaluated judging the confidence interval of ' $b$ ' value at $95 \%$ confidence level. 

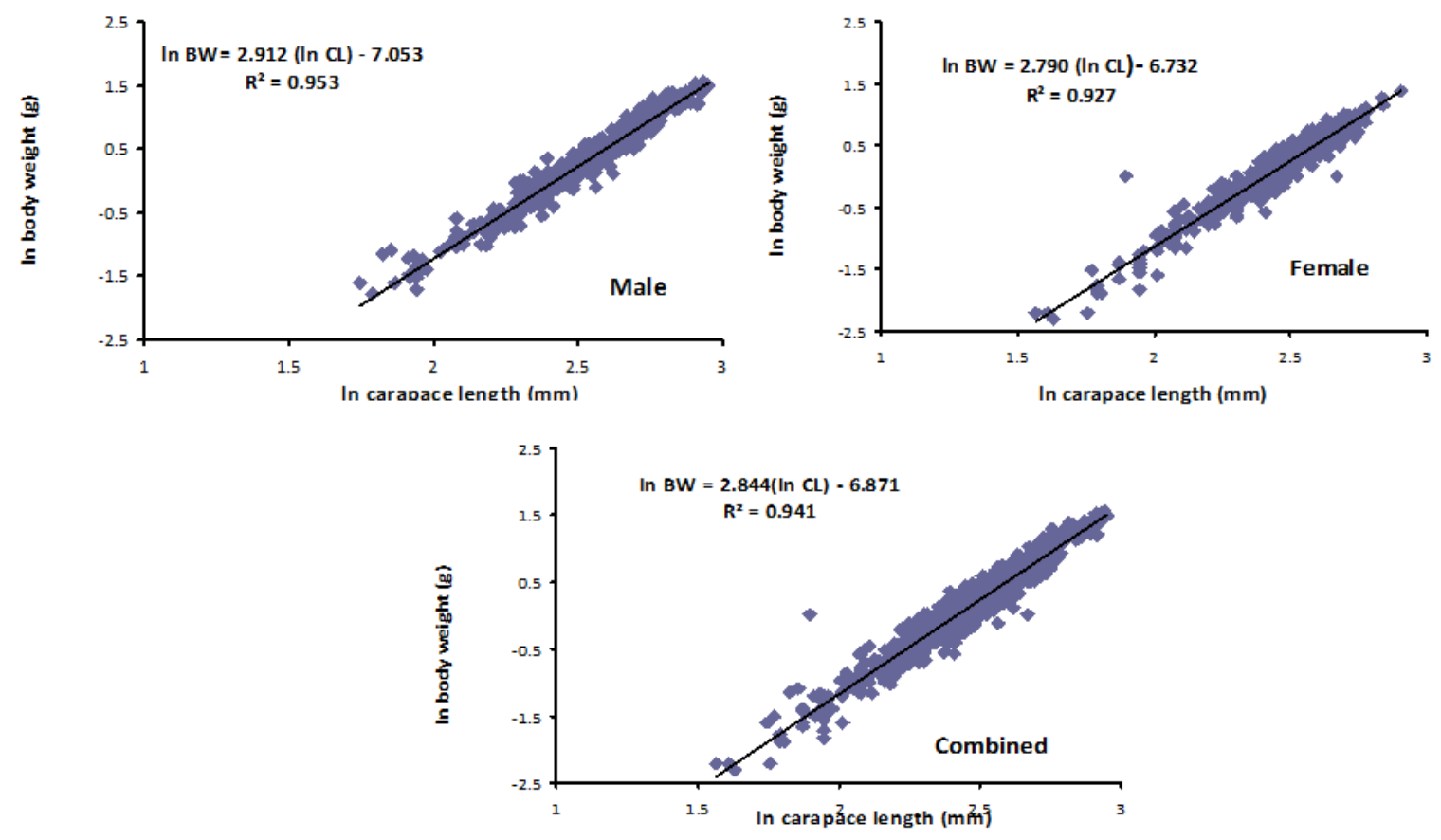

Figure 3. The generalized relationships between the natural logarithm of body weight $(\mathrm{g})$ and the natural logarithm of carapace length $(\mathrm{mm})$ in male, female and combined prawn of Macrobrachium lamarrei.
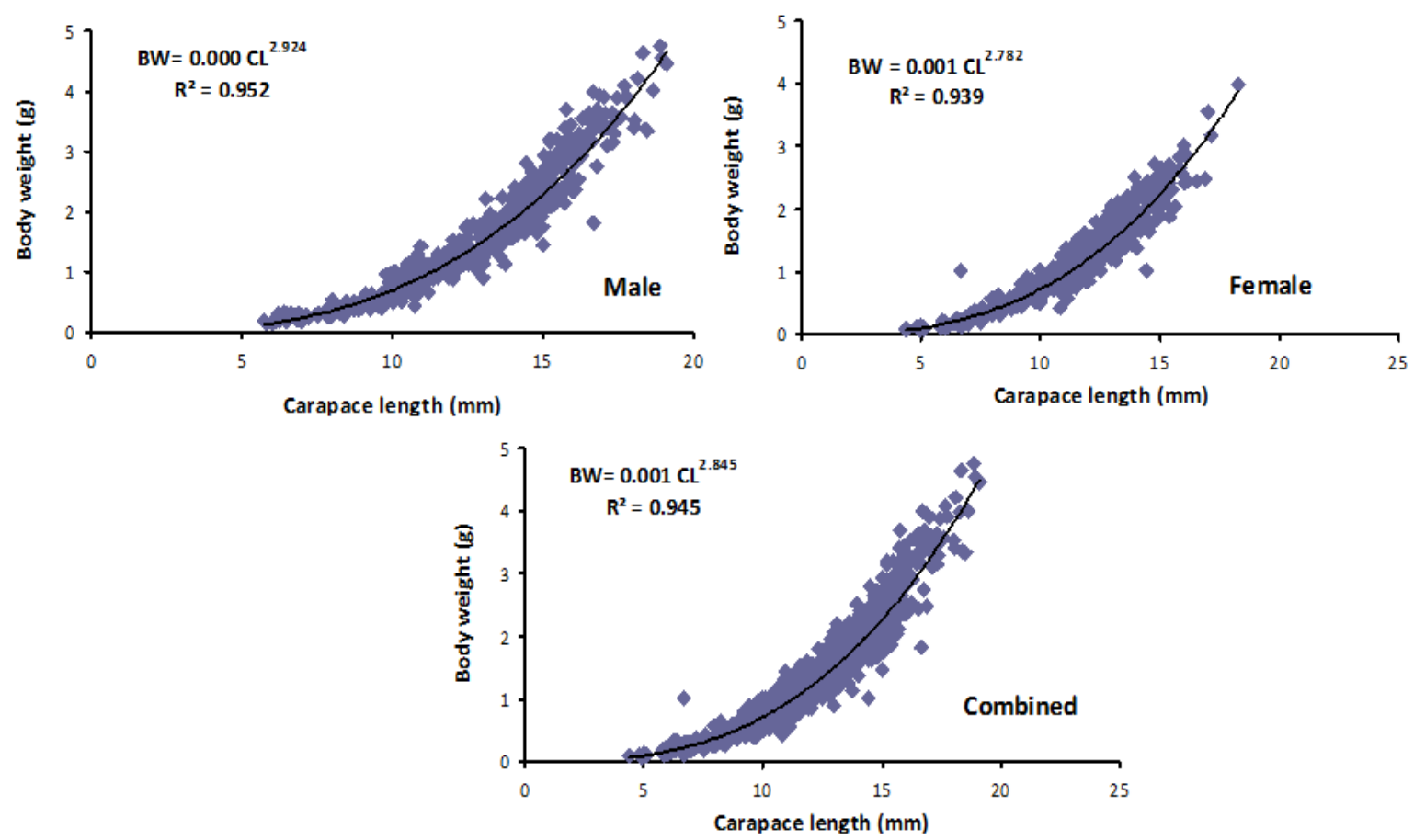

Figure 4. The generalized relationships between the body weight $(\mathrm{g})$ and the carapace length $(\mathrm{mm})$ in male, female and combined prawn of Macrobrachium lamarrei. 


\section{RESULTS AND DISCUSSIONS}

The carapace length and body weight of all monthly samples collected all over the year varied and ranged from $4.80 \mathrm{~mm}$ to $19.10 \mathrm{~mm}$ and from $0.10 \mathrm{~g}$ to $4.76 \mathrm{~g}$ respectively. A total of 1018 specimens of $M$. lamarrei were used to determine the length- weight relationship where 485 were male and 533 were female prawns showing a sex ratio 1: 1.09 (male: female). The carapace length and body weight of male ranged from $5.75 \mathrm{~mm}$ to $19.10 \mathrm{~mm}$ and from $0.17 \mathrm{~g}$ to $4.76 \mathrm{~g}$ respectively. And the carapace length and body weight of female ranged from $4.80 \mathrm{~mm}$ to $18.29 \mathrm{~mm}$ and the body weight ranged from $0.10 \mathrm{~g}$ to $3.98 \mathrm{~g}$ (Table 1 ).

Table 1. Collection record of freshwater prawn $M$. lamarrei from the $L$ shaped pond at Bangladesh Agricultural University (BAU), Mymensingh

\begin{tabular}{|c|c|c|c|c|c|c|}
\hline \multirow{2}{*}{$\begin{array}{l}\text { Sampling } \\
\text { Date }\end{array}$} & \multirow{2}{*}{$\begin{array}{c}\text { Number } \\
\text { of Male }\end{array}$} & \multicolumn{2}{|c|}{ Size Range } & \multirow{2}{*}{$\begin{array}{l}\text { Number } \\
\text { of Female }\end{array}$} & \multicolumn{2}{|c|}{ Size Range } \\
\hline & & CL(mm) & $B W(g)$ & & $\mathrm{CL}(\mathrm{mm})$ & $B W(g)$ \\
\hline January & 39 & $5.75-16.00$ & $0.18-2.36$ & 48 & $4.80-15.60$ & $0.11-2.36$ \\
\hline February & 26 & $10.00-18.00$ & $0.76-3.60$ & 41 & 6.68-15.14 & $0.45-2.50$ \\
\hline March & 37 & $6.22-18.48$ & $0.32-4.08$ & 24 & $11.05-18.29$ & $1.10-3.98$ \\
\hline April & 42 & $9.80-19.10$ & $0.81-4.76$ & 32 & $9.70-15.15$ & $0.86-2.51$ \\
\hline May & 43 & 10.93-17.31 & $1.07-3.65$ & 34 & 5.89-16.05 & $0.22-2.52$ \\
\hline June & 26 & 6.78-18.92 & $0.30-4.64$ & 39 & $7.63-15.45$ & $0.41-2.73$ \\
\hline July & 35 & 8.24-15.66 & $0.41-2.82$ & 53 & $9.22-15.35$ & $0.46-2.65$ \\
\hline August & 43 & $7.12-15.35$ & $0.25-2.11$ & 71 & $7.00-15.50$ & $0.21-2.44$ \\
\hline September & 44 & $6.00-15.30$ & $0.17-2.11$ & 53 & 8.30-15.80 & $0.31-2.83$ \\
\hline October & 55 & $6.00-13.10$ & $0.17-1.38$ & 51 & $5.00-13.80$ & $0.10-1.93$ \\
\hline November & 41 & $6.40-18.00$ & $0.34-3.53$ & 34 & $7.60-17.10$ & $0.42-3.17$ \\
\hline December & 54 & $7.00-15.00$ & $0.26-2.20$ & 53 & $8.00-17.00$ & $0.46-3.56$ \\
\hline
\end{tabular}

By establishing the relationship of body weight to carapace length different ' $a$ ' and ' $b$ ' values were found in this study for male, female and combined prawn separately. In case of male, monthly variation was found in coefficients of equations ' $a$ ' and it was from 0.00096 to 0.00333 . The maximum and minimum values of 'a' were on March and September. The slope of equations 'b' of male also varied monthly and it was from 2.4363 to 2.8229 . The maximum and minimum values of 'b' were on September and March. In case of female, monthly variation was found in coefficients of equations ' $a$ ' and it was from 0.00059 to 0.00728 . The maximum and minimum values of ' $a$ ' were on January and June. The slope of equations ' $b$ ' of female also varied monthly and it was from 2.0761 to 3.0314. The maximum and minimum values of 'b' were on June and January. This result revealed that the growth in females were isometric but negative allometric in males suggesting that female prawns were comparatively in better condition than males of the same population. 
Table 2. Monthly descriptive statistics and estimated parameters of length-weight relationships of M. lamarrei prawn species from a large perennial pond at Bangladesh Agricultural University, Mymensingh

\begin{tabular}{|c|c|c|c|c|c|c|c|c|c|}
\hline Month & Sex & $\mathbf{n}$ & a & b & $S_{e}(b)$ & $95 \% \mathrm{Cl}$ of $\mathrm{a}$ & $95 \% \mathrm{Cl}$ of $\mathrm{b}$ & $r^{2}$ & Growth Inference \\
\hline \multirow[t]{3}{*}{ January } & Male & 39 & 0.00151 & 2.67713 & 0.09078 & $0.0011-0.0023$ & $2.4932-2.8611$ & 0.95919 & Allometric \\
\hline & Female & 48 & 0.00104 & 2.80382 & 0.07238 & $0.0008-0.0015$ & $2.6581-2.9495$ & 0.97026 & Allometric \\
\hline & Combined & 87 & 0.00110 & 2.78924 & 0.05485 & $0.0009-0.0014$ & $2.6802-2.8983$ & 0.96818 & Allometric \\
\hline \multirow[t]{3}{*}{ February } & Male & 26 & 0.00156 & 2.69836 & 0.13116 & $0.0008-0.0031$ & $2.4277-2.9690$ & 0.94634 & Allometric \\
\hline & Female & 41 & 0.00728 & 2.07607 & 0.15752 & $0.0034-0.0156$ & $1.7575-2.3947$ & 0.81664 & Allometric \\
\hline & Combined & 67 & 0.00440 & 2.29152 & 0.10361 & $0.0026-0.0073$ & $2.0846-2.4984$ & 0.88271 & Allometric \\
\hline \multirow[t]{3}{*}{ March } & Male & 37 & 0.00327 & 2.43627 & 0.10228 & $0.0019-0.0057$ & $2.2286-2.6439$ & 0.94189 & Allometric \\
\hline & Female & 24 & 0.00267 & 2.53837 & 0.18698 & $0.0011-0.0072$ & $2.1506-2.9261$ & 0.89336 & Allometric \\
\hline & Combined & 61 & 0.00363 & 2.40504 & 0.08430 & $0.0023-0.0056$ & $2.2364-2.5737$ & 0.93242 & Allometric \\
\hline \multirow[t]{3}{*}{ April } & Male & 42 & 0.00185 & 2.66422 & 0.10148 & $0.0011-0.0032$ & $2.4591-2.8693$ & 0.94515 & Allometric \\
\hline & Female & 32 & 0.00342 & 2.43162 & 0.18002 & $0.0013-0.0088$ & $2.0641-2.7993$ & 0.85879 & Allometric \\
\hline & Combined & 64 & 0.00216 & 2.60819 & 0.07813 & $0.0014-0.0033$ & $2.4524-2.7639$ & 0.93931 & Allometric \\
\hline \multirow[t]{3}{*}{ May } & Male & 43 & 0.00129 & 2.79799 & 0.10942 & $0.0007-0.0023$ & $2.5770-3.0191$ & 0.94100 & Allometric \\
\hline & Female & 34 & 0.00149 & 2.72730 & 0.09532 & $0.0009-0.0024$ & $2.5331-2.9215$ & 0.96238 & Allometric \\
\hline & Combined & 77 & 0.00129 & 2.79262 & 0.05634 & $0.0011-0.0017$ & $2.6804-2.9048$ & 0.97038 & Allometric \\
\hline \multirow[t]{3}{*}{ June } & Male & 26 & 0.00184 & 2.67344 & 0.14587 & $0.0008-0.0041$ & $2.3724-2.9745$ & 0.93331 & Allometric \\
\hline & Female & 39 & 0.00134 & 2.78644 & 0.15746 & $0.0006-0.0029$ & $2.4674-3.1055$ & 0.89434 & Allometric \\
\hline & Combined & 65 & 0.00142 & 2.76582 & 0.09022 & $0.0009-0.0023$ & $2.5855-2.9461$ & 0.93717 & Allometric \\
\hline \multirow[t]{3}{*}{ July } & Male & 35 & 0.00105 & 2.80381 & 0.11113 & $0.0006-0.0018$ & $2.5777-3.0299$ & 0.95071 & Allometric \\
\hline & Female & 53 & 0.00059 & 3.03145 & 0.15581 & $0.0003-0.0013$ & $2.7187-3.3442$ & 0.88127 & Isometric \\
\hline & Combined & 88 & 0.00088 & 2.87554 & 0.08944 & $0.0006-0.0014$ & $2.6977-3.0533$ & 0.92319 & Allometric \\
\hline
\end{tabular}


Table 2. Contd.

\begin{tabular}{|c|c|c|c|c|c|c|c|c|c|}
\hline Month & Sex & $\mathbf{n}$ & a & b & $S_{e}(b)$ & $95 \% \mathrm{Cl}$ of $\mathrm{a}$ & $95 \% \mathrm{Cl}$ of $\mathrm{b}$ & $r^{2}$ & Growth Inference \\
\hline August & $\begin{array}{l}\text { Male } \\
\text { Female } \\
\text { Combined }\end{array}$ & $\begin{array}{c}43 \\
71 \\
114\end{array}$ & $\begin{array}{l}0.00114 \\
0.00077 \\
0.00081\end{array}$ & $\begin{array}{l}2.73272 \\
2.93153 \\
2.89983\end{array}$ & $\begin{array}{l}0.09232 \\
0.09812 \\
0.07301\end{array}$ & $\begin{array}{l}0.0007-0.0018 \\
0.0005-0.0012 \\
0.0006-0.0011\end{array}$ & $\begin{array}{l}2.5463-2.9192 \\
2.7358-3.1273 \\
2.7552-3.0445\end{array}$ & $\begin{array}{l}0.95531 \\
0.92825 \\
0.93372\end{array}$ & $\begin{array}{l}\text { Allometric } \\
\text { Allometric } \\
\text { Allometric }\end{array}$ \\
\hline September & $\begin{array}{l}\text { Male } \\
\text { Female } \\
\text { Combined }\end{array}$ & $\begin{array}{l}44 \\
53 \\
97\end{array}$ & $\begin{array}{l}0.00096 \\
0.00067 \\
0.00082\end{array}$ & $\begin{array}{l}2.82288 \\
2.98841 \\
2.89806\end{array}$ & $\begin{array}{l}0.09215 \\
0.09676 \\
0.06739\end{array}$ & $\begin{array}{l}0.0006-0.0015 \\
0.0004-0.0011 \\
0.0006-0.0011\end{array}$ & $\begin{array}{l}2.6369-3.0088 \\
2.7942-3.1827 \\
2.7643-3.0318\end{array}$ & $\begin{array}{l}0.95716 \\
0.94925 \\
0.95115\end{array}$ & $\begin{array}{l}\text { Allometric } \\
\text { Isometric } \\
\text { Allometric }\end{array}$ \\
\hline October & $\begin{array}{l}\text { Male } \\
\text { Female } \\
\text { Combined }\end{array}$ & $\begin{array}{c}55 \\
51 \\
106\end{array}$ & $\begin{array}{l}0.00159 \\
0.00128 \\
0.00145\end{array}$ & $\begin{array}{l}2.62406 \\
2.73920 \\
2.67235\end{array}$ & $\begin{array}{l}0.06238 \\
0.07639 \\
0.04945\end{array}$ & $\begin{array}{l}0.0012-0.0021 \\
0.0009-0.0018 \\
0.0012-0.0018\end{array}$ & $\begin{array}{l}2.4989-2.7492 \\
2.5857-2.8927 \\
2.5743-2.7704\end{array}$ & $\begin{array}{l}0.97092 \\
0.96329 \\
0.96562\end{array}$ & $\begin{array}{l}\text { Allometric } \\
\text { Allometric } \\
\text { Allometric }\end{array}$ \\
\hline November & $\begin{array}{l}\text { Male } \\
\text { Female } \\
\text { Combined }\end{array}$ & $\begin{array}{l}41 \\
34 \\
75\end{array}$ & $\begin{array}{l}0.00221 \\
0.00227 \\
0.00225\end{array}$ & $\begin{array}{l}2.53743 \\
2.53001 \\
2.53063\end{array}$ & $\begin{array}{l}0.06925 \\
0.11811 \\
0.06102\end{array}$ & $\begin{array}{l}0.0016-0.0031 \\
0.0013-0.0040 \\
0.0017-0.0030\end{array}$ & $\begin{array}{l}2.3974-2.6775 \\
2.2894-2.7706 \\
2.4090-2.6522\end{array}$ & $\begin{array}{l}0.97177 \\
0.93481 \\
0.95929\end{array}$ & $\begin{array}{l}\text { Allometric } \\
\text { Allometric } \\
\text { Allometric }\end{array}$ \\
\hline December & $\begin{array}{l}\text { Male } \\
\text { Female } \\
\text { Combined }\end{array}$ & $\begin{array}{c}54 \\
53 \\
107\end{array}$ & $\begin{array}{l}0.00122 \\
0.00174 \\
0.00152\end{array}$ & $\begin{array}{l}2.79011 \\
2.65731 \\
2.70523\end{array}$ & $\begin{array}{l}0.10109 \\
0.04818 \\
0.05102\end{array}$ & $\begin{array}{l}0.0007-0.0020 \\
0.0014-0.0022 \\
0.0012-0.0021\end{array}$ & $\begin{array}{l}2.5872-2.9931 \\
2.5606-2.7540 \\
2.6041-2.8064\end{array}$ & $\begin{array}{l}0.93611 \\
0.98351 \\
0.96399\end{array}$ & $\begin{array}{l}\text { Allometric } \\
\text { Allometric } \\
\text { Allometric }\end{array}$ \\
\hline
\end{tabular}

$\mathrm{n}$ : number of specimens, a: coefficient parameter of length-weight relationship, b: slope of length-weight relationship , Se(b): standard error of b, Cl: confidence interval,

$r^{2}$ : coefficient of determination 
In case of combined prawn, monthly variation was found in coefficients of equations ' $a$ ' and it was from 0.00081 to 0.00440 . The maximum and minimum values of 'a' were on February and August. The slope of equations ' $b$ ' of combined prawn also varied monthly and it was from 2.2915 to 2.8998. The maximum and minimum values of ' $b$ ' were on August and February. This result agrees with the finding of Soomro et al. (2012) for Macrobrachium malcolmsonii. They found the values of $b$ were 2.97 for males and 3.04 for females indicating the growth was isometric for female and allometric for male.

Table 2 illustrated that the length-weight relationships of male M. lamarrei prawn species indicated negative allometric growth in all months over a calendar year. Similarly in female prawns, the length-weight relationships indicated negative allometric growth in all months except July and September where the growth was isometric. But in combined population the length-weight relationships indicated negative allometric growth for all the months over a calendar year. Finally, this study constructed the generalized length-weight relationship of all monthly samples for male, female and combined prawn that were $\mathrm{BW}=0.0008 \mathrm{CL}^{2.924}$, BW $=0.0012 \mathrm{CL}^{2.783}$ and $\mathrm{BW}=$ $0.0010 \mathrm{CL}^{2.845}$ respectively. Lalrinsanga et al. (2012) reported similar results for $M$. Rosenbergii prawn and the length weight relationship were $W=0.073299 L^{3.5502}, W=0.102962 L^{3.2443}$ and $W=$ $0.087694 L^{3.3893}$ for male, female and total prawn respectively. In the present study, analysis of covariance revealed significant differences between sexes for the slopes ' $b$ ' of the regression lines $(P<0.05)$, with all coefficient of determination values being $>0.904$.

\section{CONCLUSION}

Length-weight relationship (LWR) is an important fishery management tool (Bagenal and Tesch, 1978; Gonzalez Acosta et al., 2004). They are used for various aspects including estimation of weight from length observations, calculation of production and biomass in the assessment of fish populations, in addition providing information about body condition of specimens in stocks or populations (Lai and Helser, 2004; Gerritsen and McGrath, 2007). Information regarding any biological aspects of $M$. lamarrei prawn species from Bangladesh waters is quite insufficient. To the best of our knowledge, no references dealing with length-weight relationship (LWR) for M. lamarrei is available from Bangladesh waters. Therefore, this study presents the first attempt to describe this length-weight relationship for the $M$. lamarrei species from Bangladesh. In conclusion, this study has provided the first basic and baseline information on the LWR that would be beneficial for fishery biologists and conservationists to impose adequate regulations for sustainable fishery management and conservation of biodiversity for this species in Bangladesh. Further, the information provides a platform for future research into other growth and reproductive attributes of this fish species.

\section{REFERENCES}

1. Anderson R and S Gutreuter, 1983. Length, weight and associated structural indices. In: Fisheries techniques (eds. L. Nielson and D. Johnson.). American Fisheries Society, Bethesda. pp. 283-300.

2. Bagenal TB and FW Tesch, 1978. Age and growth. In: Methods for Assessment of Fish Production in Fresh Waters, 3rd edit. (Begenal T, ed.). Blackwell Science Publications, pp.101-136.

3. Gerritsen HD and D McGrath, 2007. Significance differences in the length-weight relationships of neighbouring stocks can result in biased biomass estimates: Examples of haddock (Melanogrammus aeglefinus, L.) and whiting (Merlangius merlangus, L.). Fisheries Research, 85: 106-111.

4. Gonzalez Acosta AF, GD Aguero and JD Lacruz Aguero, 2004. Length-weight relationships of fish species caught in a mangrove swamp in the Gulf of California (Mexico). Journal of Applied Ichthyology, 20: 154-155. 
5. Holthius, LB 1980. FAO Species Catalogue, shrimps and prawns of the world. An annoted catalogue of species of interest to fisheries. FAO Fisheries Synopsis, 125 271p.

6. Hossain MY, ZF Ahmed, PM Leunda, AKMR oksanul Islam, S Jasmine, ZJ Osco, R Miranda and J Ohtomi, 2006. Length-weight and length-length relationships of some small indigenous fish species from the Mathabhanga River, southwestern Bangladesh. Journal of Applied Ichthyology, 22: 301-303.

7. Hossain MY, J Ohtomi, A Jaman, J Saleha and LVJ Robert, 2012. Life history traits of the Monsoon River prawn Macrobrachium malcolmsonii (Milne-Edwards, 1844) (Palaemonidae) in the Ganges (Padma) River, northwestern Bangladesh. Journal of Freshwater Ecology, 27: 131-142.

8. Lai HL and T Helser, 2004. Linear mixed-effects models for weight-length relationships. Fisheries Research, 70: 377-387.

9. Lalrinsanga PL, RP Bindu, G Patra, S Mohanty, NK Naik and S Sahu, 2012. Length weight relationship and condition factor of giant freshwater prawn Macrobrachium rosenbergii (De Man, 1879) based on developmental stages, culture stages and sex. Turkish Journal of Fisheries and Aquatic Sciences, 12: 917-924.

10. Mantelatto FLM and LR Barbosa, 2005. Population structure and relative growth of freshwater prawn Macrobrachium brasiliense (Decapoda, Palaemonidae) from São Paulo State, Brazil. Acta Limnologica Brasiliensis, 17: 245-255.

11. Martin-Smith $\mathrm{KH}$, 1996. Length- weight relationship of fishes in a diverse tropical freshwater community, Sabah, Malaysia. Journal of Fish Biology, 49: 731-734.

12. Mir JI, UK Sarkar, AK Dwivedi, OP Gusain, A Pal and JK Jena, 2012. Pattern of intrabasin in condition factor, relative condition factor and form factor of an Indian Major Carp, Labeo rohita (Hamilton- Buchanan, 1822) in the Ganges Basin, India. European Journal of Soil Biology, 4: 126135.

13. Pauly D and FC Jr. Gayanilo, 1996. Estimating the parameter of length-weight relationship from length-frequency samples and bulk weights. $23321 \mathrm{p}$.

14. Sarkar UK, PK Deepak and RS Negi, 2008. Length- weight relationship of clown knife fish chitala chitala (Hamilton, 1822) from the Ganga basin, India. Journal of Applied Ichthyology, 25: 232-233

15. Singh NO, D Sarma and NG Singh, 2011. Length- weight relationship of Tor putitora (Hamilton) from Kosi River, Uttarakhand considering different stages of its lifespan. Indian Journal of Fisheries, 58: 35-38.

16. Soomro AN, WA Baloch, TJ Chandio, WM Achakzai and S Saddozai, 2012. Condition factor and length-weight relationship of monsoon river prawn Macrobrachium malcolmsonii malcolmsonii $(\mathrm{H}$. Milne-Edwards, 1844) (Palaemonidae) in lower Indus river. Pakistan Journal of Zoology, 44: 12791283. 